\title{
Local Culture Implementation in Multicultural Education Practice for Early Childhood
}

\author{
Febritesna Nuraini \\ PGPAUD UAD, Indonesia
}

Corresponding e-mail: febritesna@gmail.com

\begin{abstract}
Multicultural education be made important to early childhood education. The current trend in most countries cultural conflicts and problem human behaviour. Multicultural education is a system that encourages schools to internalize social consciousness and team work skill in any context of diversities. This paper is aimed to describe the effectiveness of integrated planning of the multicultural education process for early childhood education. There are three steps in implementing the multicultural education, 1) integrating multicultural education in the curriculum, 2) arranging knowledge process, 3) movement of equation.
\end{abstract}

Key words: Local Culture, multicultural, early childhood

\section{INTRODUCTION}

Education is not only part of social life, but also part of national life which has important role for improving the capacity and stability of human resources. Along with the improvement of human resources, it will give effect toward the resource management and the competitiveness in developing country.

In detail, the national education goal is outlined in the National Education Act No. 20 of 2003 as follow.

"The National Education is aimed at developing learners' potentials so that they become persons imbued with human values who are faithful and pious to one and only God; who possess morals and noble character; who are healthy, knowledgeable, competent, creative, independent; and as citizens, are democratic and responsible."

The aim of National Education has given a clear illustration about the scope of the National Education implementation which considers the cultural background and cultural diversity of the nation. It is because culture diversity becomes inseparable aspect of a region independency.

Indonesia is a multicultural country which consists of various islands, ethnicities, religions, and cultures. There are more than 13.000 small and big islands, 300 ethnics, and 200 languages.

Furthermore, there are also several religions such as Islam, catholic, Kristen, Hindu, Buddha, and other religious groups.

The cultural diversity in Indonesia consequently causes many problems. Previously, the problems in Sampit, Ambon, and Irian Jaya where clashes between groups with primordial ties resulted in loss of life and property. Clash of cultures, race, ethnicity, religion and values in society would threaten the integrity and resilience of the Indonesian people. Based on the above phenomenon, it is not excessive if we, as a multicultural society should be wary of the clash of civilizations as stated by Samuel P Hungtion.

The loss of national identity among the young generation is another issue that arise. Furthermore, the rapid flow of global information that affects the penetration of foreign culture influences the mindset, attitudes and behaviour. The problem of deviant behaviour which override moral values and ethics such as stealing, queuing culture, cheating, as well as environmental damage such as littering haphazardly are mostly caused by acculturation and urbanization factors. Thus, the deviant behaviour 
that appears today is the result of the long-standing life pattern.

To overcome those problems above, it is needed to find an effective problem solving. The problem solving should cover various areas such as social, political, cultural, economic and education. To solve the problem of human behaviour that has been entrenched, it is necessary to have synergies from various aspects, particularly education aspect. Education is the most effective effort to give colour to the individual.

Education is an important element of one's life and a strategic aspect of a country in providing good quality of human resources. Education is also a prime mover development in character building. Education is held in a democratic and fair way to uphold human rights, religious values, cultural values and the nation's progress. The education process is carried out through three channels namely formal, non-formal and informal education where all three can be complementary one another. Conceptually, education is multicultural but in Indonesia, the implementation of education emphasizes on the competition aspect that tend to create individualistic people (Suyato, 2016)

Considered very important to provide multicultural education as a new discourse in the education system in Indonesia, especially learners to have sensitivity in dealing with the symptoms and social problems are rooted in differences of race, ethnicity, religion and values that exist in society. In this case, can be implemented in substance and learning model that recognizes and respects cultural diversity, as equip them to face the problems and to train the personality of the learner.

In effect, meaningful multicultural education to prepare all students to work actively towards the structural similarity in communities and school institutions. Multicultural education is not a policy that leads to educational institutions, and inclusive teaching through curriculum that contribute to individual cultural competitions. Multicultural education empowers learners to develop respect, cooperate and respect towards other people.

Developing respect, cooperation and mutual respect among students can be done from an early age. Ainul Yakin (2006) stated that giving multicultural education to early childhood is very important in order that they are able to recognize their environment that has various kinds of cultural diversity. This is because cultural diversity influences people behaviour, attitude, way of thinking so that people have different ways of life, habit, rules, even customs.
Based on the phenomena now days, this paper offers alternative strategy and concept which are based on utilization of the diversity that exists in the community through the local cultures, especially those that are close to the students' life like gender, age, culture, language, religion, ethnicity, and social status. This alternative strategy is not only helping students to recognize local cultures but also encouraging them to improve their good behavior. Novia Wahyu wardani (2013) stated that learning the local wisdom values in education has strong connection with the stages of internalization of values to raise awareness of being well behaved.

Based on the background above, the formulation of problems are as follow; 1) Factor that the influence implementation of the local culture implementation in multicultural education practice for early childhood, and 2) How is the stages of implementation of local culture as a reinforcement of multicultural education.

\section{THEORETICAL REVIEW}

\subsection{Multicultural Education}

The diverse life today requires good understanding about multicultural dimension in broadening the discourse of individual thinking which tent to be individualist and egocentric. Multicultural education is a set of belief which explains and also evaluates the importance of culture and ethnical diversity in establishing life style, social experiences, personal identity, and education opportunity weather individual, group, and nation (Banks: 2003).

Haviland explained that multi-culture means plurality of culture or it means rejection of fanaticism, preconception, racism, materialism and accept diversity (william Haviland, ter. 1998).

Multicultural Education is an idea, education reform movement, and education process which is aimed to change the structure of education institution so that male and female students, students with disability, students from different ethnicity and culture get the same opportunity to have academic achievement in school.

Howard stated that multicultural education gave multicultural competency. Therefore, multicultural education should be taught to early age children, so that they are able to accept and understand culture diversity in the form of different way of life, habits, rules, and customs in society. Multicultural education subject at school is aimed to build student's character so that students are able to 
accept different way of thinking, be tolerant, be careful, be empathetic to others without considering their background.

Parekh state that multiculturalism involves three aspects; first, multiculturalism in culture aspect, second multiculturalism in diversity, and third multiculturalism in specific act at the response toward diversity.

The goal of multicultural education is changing the individual's view in gaining opportunity through learning approach. Students should be taught to appreciate diversity and uniqueness. It means that it needs to change student's attitude, behavior and values of mutual respect.

\subsection{Local Culture}

According to Brennan (2009) states that the concept of local culture has many definitions and perspectives. Social side, the usual is broadly defined to include the whole way of life, including law, the value of the desired behavior. In principle, the culture can be seen as a universal thought. This thought pattern from time to time so that it becomes a habit in a particular community.

The Judistira (2008) says that the local culture is not revealed on the forms and statements sheer sense of beauty through art, but includes all forms, ways of behaving, acting, as well as patterns of thought that are far behind what looked to them. Local culture is local values manifestation from people at certain region that is formed naturally through learning process from time to time. Local culture can be in forms of works of art, traditions, and patterns of thought or customary law. So, local culture is culture that grows and develops in society and belongs to that society at certain region.

Local culture and regional are formed when people in certain place or region have similar way of thinking and social life that are different with other places and regions.

\subsection{Characteristic of Early Childhood}

Early age is golden age where children are probable to be stimulated. NAECY stated that early childhood is $0-8$ years old children, while based on the National Education Act, early childhood is 0-6 years old children.

Based on the Development a Priory Program (DAP), at early age, children are potential to be stimulated because they have thousands of neutrons interconnected one another. DAP become a reference for Early Childhood Education (PAUD) curriculum in Indonesia. Based on the curriculum, stimulus is given to the children gradually adjusted to children development through game activities.

\subsection{Multicultural Learning Model}

Schools that have multicultural learning should specify their multicultural learning model and learning material development which are applicable for them, particularly early childhood education institution.

Multicultural education model should be also integrated in learning activities. Activity model of early childhood learning is given through direct example, traditional games, and additional supplement of subject material. This learning activity is developed by considering the transformation approach and social action so that the material for student can be directly implemented in daily life. Multicultural education model emphasizes on the equality of treatment between school and home so it can be well implemented.

\section{DISCUSSION}

\subsection{Factor that the influence implementation of the local culture implementation in multicultural education practice for early childhood.}

Multicultural education is a reformation movement in process of designing education environment that is equal for students. Commonly, people are not familiar with the term of multicultural education. Furthermore, they also have different interpretation toward it.

As a reformation movement and a process of creating equal education environment for all students, multicultural education has some principals as follows;

1. Multicultural education is political movement which is aimed to ensure social equality for all Indonesian people without regarding their background.

2. Multicultural education considers two interconnected dimensions of learning (class) and institution (school). Both dimensions cannot be separated and should 
be run together and comprehensively through curriculum.

3. Multicultural education emphasizes on education reformation that can be comprehensively achieved through critical analysis toward privileges power systems for the comprehensive reformation action in education.

4. Based on the core critical analysis, the goal of multicultural education is providing students the assurance to get opportunity maximally.

5. Multicultural education is the best education for students without considering their background.

In this paper, the concept of multiculturalism emphasizes on viewing the world with frame of local culture reference and identifying as well as appreciating the richness of culture diversity. It also emphasizes on developing schools which contains of different race, ethnicity, gender, religion, culture, sexual orientation, and economy. Those differences are considered as valuable sources to enrich teaching learning process.

Teaching learning process or learning activity process is complex process which all involved factors cannot be totally managed by teacher or education institution (school). Based on Maurianne Adams and Barbara J. Love (2006), there are four factors in the learning process, namely 1) congenital factor of student, 2) congenital factor of teacher, 3) pedagogy factor, and 4) curriculum content factor. Those factors can be illustrated as follow:

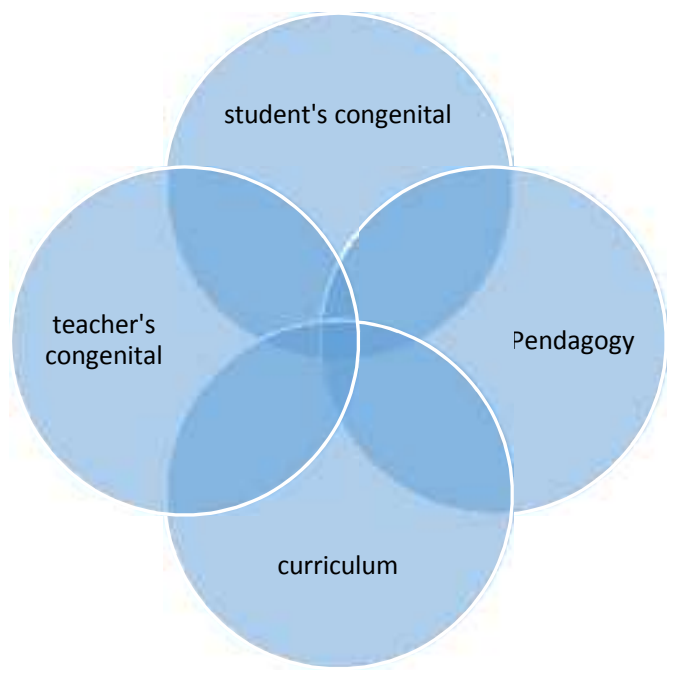

Picture 1. Factors in learning
In the multicultural education, those factors influence the teaching learning process. The first factor, teachers have different behavior one another. For example, the way teacher entering class room or preparing students to enter class room is different based on the teacher's congenital. The congenital can be characterized by the society or the teacher self. The second factor, students also have different characteristic one another. The third factor, pedagogy has different meaning and impact when it is implemented by different teachers. The fourth factor, curriculum can be interpreted differently and give different impact toward students.

The fourth factors are interconnected one another. Failing in construction process causes negative impact for students who has limitation in gaining the goal of learning and do the opposite.

\subsection{Stages of implementation of local culture as a reinforcement of multicultural education.}

\subsubsection{Integrating Multicultural Education into Curriculum}

Multicultural education as a transformation process require a long period of time to gain the ultimate goal. According to James a Banks (1993) In integrating multicultural education into curriculum, there are four approaches as follows:

1) Contribution Approach

This is the easier approach for school in integrating culture material and multiculture into curriculum.

The main characteristic of this approach is putting National hero and typical cultural objects into curriculum by selecting them using culture parameter that is well known in the society. For example, the national heroes, Raden Ajeng Kartini and Pangeran diponegoro are put in the curriculum and discussed at Hero's days or at independent day. Typical culture elements like food, dance, and music instrument also can be taught through daily learning activities at school. The most important thing is that teacher should give meaning and importance of those typical culture to students.

The important characteristic of contribution approach is that it does not 
change the basic structure, goal, and characteristic of the existing curriculum main stream. The requirement in implementing this approach is only basic knowledge about society in certain region and about ethnicity hero with the role and contribution to the society.

Contribution approach is also early approach for teacher to integrate culture material into curriculum.

This approach in another hand has some weaknesses. Heroes and culture contribution integrated in the curriculum cannot give global illustration about the role of each culture.

This contribution approach into material can give students an instant experience through the role of heroes in developing a region, but it sometime fails in helping student to comprehend the heroic role in the whole context of history. If heroic material is only taught separately and only part of small context of social and politic where the hero lived, then students only get partial understanding about the role in society.

2) Additive Approach

This approach discussing about the interaction between culture material emphasizing with the addition of material, concept, theme, and perspective toward curriculum without changing the structure, goal, and its basic characteristic. In this approach, there is usually an additional book, unit, or domain in the curriculum without any substantial changes. Example of this approach is additional book of folklore, traditional game as learning source, and local language.

Additive approach gives opportunity for teacher to add local culture material into curriculum without restructuration, a process that require time, effort, practice, and rethinking about meaning, purpose, and characteristic of the curriculum. Additive approach can be the initial phase in transformative curriculum reform efforts designed to totally reconstitute curriculum and to integrate with the material, perspective, and thought frame of culture.

3) Transformation Approach This approach is basically different with previous approaches. In this transformation approach, there are changes of purpose, structure, and fundamental perspective of curriculum.

Transformation approach transforms the basic assumption of curriculum and builds student's competency in viewing the concept, issue, theme and problem from various perspectives and cultural point of views.

4) Social Action Approach This approach covers all elements of transformation approach with adding component that requires students to make decision and to act related to the learning activity being in progress. The main purpose of learning in this approach is teaching students to do action of social change and teaching them skill of making decision. Furthermore, this approach strengthens students and help them to get efficacy in understanding behavior.

\subsection{Process of Knowledge Construction}

This process emphasizes of teacher's process in helping students to get full understanding. The Philosophy of Ki Hajar Dewantara has formulated management of educational situation of the teacher with a well-known philosophy "Tut Wuri Handayani”(Taman Siswa 60 Tahun, in Dirdo). Dirdo Hadi Kusomo explained the three philosophy of "Ing Ngarso Sung Tuloda, Ing Madyo Mangun Karso, Tut Wuri Handayani". The philosophy of Ki Hajar Dewantara is native for Indonesian people and becoming reference in the process of constructing early childhood knowledge. Considering the unique characteristics of early age students, it will influent the personal establishment of the student's behavior that is appropriate with local culture. The model of local behavior is also close to the student and relevant with the development phase of children, and early childhood learning.

"Ing Ngarso Sung Tulodo" in context of early childhood education is similar with the cognitive social theory Bandura in which educators (teacher and parent) become role model in helping students to understand behavior so that students are able to have full understanding.

"Ing Madyo Mangun Karso" in context of early childhood education emphasizes on the internalization of multicultural education by giving motivation to the students in getting involved in any activity they have in order to get complete understanding. 
"Tut Wuri Handayani” means teachers assisting and escorting students from behind so that teacher can give help if the students are in difficult situation. Teachers also help to raise the student's self-esteem so that students become more independent and are able to overcome their problem.

\subsection{Movement of Equation}

This movement is the real action rather than a discussion in scientific forum. In early childhood education, this movement focuses on the equation between school and home so that students capture the integral example from educators around them. Movement of equation not only involves school community but also all elements of the children environment to have the same contribution. Banks (2001) stated that multicultural education is the way to see the reality and also the way of thinking. It is not only content about a variety of group, ethnicity, race, and culture. In specific, Banks explained that multicultural education can be conceptualized as a dimension of integral contents, the content of the way teacher utilizing examples with the content of culture variety and group representing culture. Learning activity also give lesson about mutual cooperation "sambatan", a joint activity with other people in a society without any salary. This mutual cooperation can be taught to students when they are playing in groups. In this group learning, teacher gives folklore at the beginning of the lesson.

All students' activities in classroom should be informed to their parent so that the students have the same pattern of activities.

\section{CONCLUSION}

From the elaboration above, it can be concluded some points as follow;

1. Multicultural education is a reality, a consciousness of culture variety, human right, and the elimination of preconception in society.

2. It is important to give multicultural education at early childhood to head the cultural pluralism.

3. Multicultural education is a new paradigm which is tolerable and elegant for anticipating cultural impact.

4. The practice of multicultural education emphasizes on local culture by considering the learning basic principles of early childhood education.

\section{REFERENCES}

Banks, J.A. (1993). Multicultural Education: Issues dan Perspectives. Needham Height, Massachusetts: Allyn and Bacon.

Banks, James A \& Banks, Cherry A. McGee. (2001).Multicultural Education:Issues \& Perspectives. 4th ed. The United of America: John

Wiley \& Sons,Inc. Banks, James A.(ed).(2003). Thriving in the Multicultural Classroom (Principle and Practices for Effective Teaching): Multikultural Education Series. NewYork: Dilg, Mary.

Brooker, Liz \& Woodhead, Martin. (2008). Developing Positive Identities (Early Childhood in Focus 3: Diversity and Young Children). United Kingdom: Thanet Press Ltd, Margate.

Brennan, M.A (2010). The Importance of incorporatinglokal culture into community Development: an international of education jurnal.

Garna, Judistira K (2008). Sunda culture; Melintasi waktu Menantang Masa Depan. Lemlit Unpad Bandung.

Lwin, May. et al. (2003). How to Multiplay Your Child's Intelligence . Alih Bahasa: Christine Sujana. Indonesia: Penerbit PT Indeks.

Naim, Ainul dan Achmad Sauqi. (2008). Education Multicultural. Concept and aplication. Yogyakarta: Ar-Ruzz Media.

Novia Wahyu wardani. Learning Values of local wisdom. Iurnal Education Research. Volum 14. No.1 April 2013.

National Education Act No. 20 of 2003 as follow. 